\title{
Using Remote Sensing Technics for Land Use Land Cover Changes Analyses from 1950s to 2000s in Somone Tropical Coastal Lagoon, Senegal
}

\author{
Ndéye Yacine Barry ${ }^{1, *}$, Mamadou Lamine Ndiaye ${ }^{2}$, Celestin Hauhouot ${ }^{3}$, Bienvenu Sambou ${ }^{4}$ \\ ${ }^{1}$ West African Science Service Center on Climate Change and Adapted Land Use (WASCAL), University of Felix Houphouet-Boigny, \\ Abidjan, Côte d'Ivoire \\ ${ }^{2}$ Laboratory of Education and Research in Geomatics, Cheikh Anta Diop University, Dakar, Senegal \\ ${ }^{3}$ Department of Geography, Felix-Houphouet-Boigny University, Abidjan, Ivory Coast \\ ${ }^{4}$ Environnemental Science Institute, Cheikh Anta Diop University, Dakar, Senegal
}

Email address:

ndyacine.barry@gmail.com (N. Y. Barry)

${ }^{*}$ Corresponding author

\section{To cite this article:}

Ndéye Yacine Barry, Mamadou Lamine Ndiaye, Celestin Hauhouot, Bienvenu Sambou. Using Remote Sensing Technics for Land Use Land Cover Changes Analyses from 1950s to 2000s in Somone Tropical Coastal Lagoon, Senegal. American Journal of Remote Sensing. Vol. 7, No. 2, 2019, pp. 35-49. doi: 10.11648/j.ajrs.20190702.12

Received: September 3, 2019; Accepted: September 24, 2019; Published: October 14, 2019

\begin{abstract}
In many developing countries, some natural areas are faced with gaps in appropriate map coverage mainly on land use and land cover (LULC) changes. This situation makes it difficult to plan and implement natural environmental protection and natural resource management programs. Remote sensing and geographic information systems (GIS) are excellent tools for mapping LULC changes. This study investigated LULC changes in 'Somone' coastal lagoon in Senegal using multisource remote sensed data. Data sets included aerial photographs recorded in March 1954, and February 1978, as well as satellite images recorded in February 2003 and April 2016. All images were geometrically corrected and segmented. Photos and/or images interpretations were made with the aid of computer and post-classification change detection technique was applied to classify multisource data and to map changes. Stratified sampling was used to assess all classification results. The accuracies of image classifications averaged 65\% (1954), 62\% (1978), 79\% (2003) and 88\% (2016). The postclassification analysis resulted in the largest overall accuracy of $66,72.7,72.4$ and $80.6 \%$ for the $1954-1978,1978-2003$ and 2003-2016 image pairs, respectively. Results indicated an increase in Settlements, from $0.29 \%$ in 1954 to $9.21 \%$ in 2016, the expansion of the Sabkha, from 5.29\% in 1954 to $18.48 \%$ in 2016 . The mangrove forest has experimented a reduction between 1954 and 1978 (from $4.07 \%$ to $0.56 \%$ ) and a regeneration (linked to the protection and preservation policies within the protected area) from the year 2003 to 2016 (from 1.44\% to 2.65\%). However, the forest areas were greatly reduced (from $51.06 \%$ in 1954 to $10.86 \%$ in 2016) and replaced by Settlements (urbanization) as well as Croplands.
\end{abstract}

Keywords: Multi-source Data, Remote Sensing, LULC Changes, Visual Interpretation Assisted by Computer, Somone Coastal Lagoon, Senegal

\section{Introduction}

Remote sensing is an invaluable working tool for environmental development and monitoring [1-7]. Among the most common applications of remote sensing data are the production of thematic maps and change detection because of repetitive coverage at short intervals and consistent image quality [8-12]. In the last few decades, remote sensing data has widely being used to detect and monitor environmental changes [11, 13-15]. Change detection is the process of identifying differences in the state of an object or phenomenon by observing it at different times [12]. Timely and accurate change detection of Earth surface features provides the foundation for greater understanding of the relationships and interactions between human and natural 
phenomena [16].

Land Use refers to human purpose or intent applied to these attributes. It includes cultivation in various forms, livestock grazing, settlement and construction, reserves and protected lands, and timber extraction [17, 18]. "Land cover" on the other hand is defined as the biological and the physical characteristics/attributes of the land surface, which includes both natural and human made materials such as trees, buildings, grass, water, asphalt and any other objects that cover the surface of the earth [19].

Land cover changes stemming from human land uses constitutes a major source and a fundamental element of global environmental change [18]. LULC changes seriously affect the environment and its processes [20]. This information is critical for the management of natural resources, the conservation of ecosystems and biodiversity as well as decision support for sustainable development [21].

The availability of remote sensing data with improved spatial, spectral and temporal resolutions should be fully exploited for a specific application subject to the relative advantages and the limitations of each sensor's data [22]. Change detection often involves comparing aerial photographs or satellite imagery, or both at different times [23]. In recent decades, integration of multisource data (e.g. aerial and satellites photographs, TM, SPOT and previous thematic maps) became an important tool for land-use and land-cover change detection, especially when the change detection involved long period intervals associated with different data sources, formats and accuracies or multi-scale land-cover change analysis [17, 24-37]. In fact, multisource approach becomes increasingly important with the availability of a variety of satellite imagery [37]. Globally, application of remote sensing technology for monitoring and evaluating coastline resources monitoring and evaluation has been practiced for about three decades is well-recognized [38-41]. Coastal lagoons are prominent features along many of the worlds sandy coasts and some type of lagoon systems compose a substantial extent of the world's coastlines [42]. These ecosystems are included in areas exposed to several LULC changes, which affect its functioning and its biodiversity [19].

The use of multisource remote sensing data for coastal resources management is very limited in Senegal, even though they are being whereas they are undergoing a very highly degradation degraded due because of to anthropogenic actions and climate change. The consequences of this degradation result include but not limited to loss biodiversity, destruction of natural habitats. [43]. This was partly due to the lack of understanding of LULC dynamics, in Senegal's coastal lagoons, specifically in Somone protected lagoon on the western coast of Senegal. But according to the [44], nowadays, it is becoming increasingly important to know how LULC has changed over the time, in order to assess changes and their impacts on ecosystems' habitats and communities' lives. The cartographic gaps observed in Somone Nature Reserve constrain sustainable management programs. The few cartographic works on LULC changes, at the scale of Somone lagoon found in the literature does not provide any information, among other things, on the quality of data sets used, the period of data acquisition, the source of the ground control points (GCPs) and the geometric accuracy of images after their correction, the classification technique used and the reason on the choice of Region of Interest (ROI), on classification validation protocol and the accuracy of change images. These are the basic questions to be answered in order to achieve a dynamic mapping of LULC.

Indeed, Senegal possesses a multisource remote sensing data-collection archive, that is more than half a century old. The first aerial photographs shot of Senegal dates back in 1940s with the United States Geological Survey (USGS) mission of April the $4^{\text {th }} 1942$. Then, there are the aerial missions of the National Institute of Forestry and Geographical Information (IGN) carried out in 1954, 1966, 1978 and 1997. Additionally, the coverage area of the coastal strip of Senegal in March 1989 by the Japan International Cooperation Agency (JICA). There are also satellite photographs of Corona program, which was once a military operation and became secret until 1992, and then declassified on February the $22^{\text {nd }}, 1995$ [45]. According to [31], the photographs offer an opportunity to look back in time and extract information at a level of detail unmatched by even present-day, civilian satellite remote sensing imagery. The launch of the first Landsat satellite (named the "Earth Resource Technology Satellite", ERTS-1) in 1972 opened an era of monitoring Earth's terrestrial surface by space-borne, remotely sensed imagery [45]. This is Landsat program with the Multi-Spectral Scanner System (MSS) and Return Beam Vidicom (RBV). Over the years, three other generations of Landsat sensors have been developed, Thematic Mapper (TM), Enhanced Thematic Mapper $(\mathrm{ETM}+)$ and Operational Land Imaging/Thermal Infrared (OLI/TIRS). Subsequent development in the sensor technology provided improved spatial, spectral, radiometric and temporal resolution to the user community that has helped in deriving timely and improved information on natural resources degradation [46]. From the 2000s, there has been emergence of new satellite sensors that provide high and very high spatial and spectral resolutions: SPOT, Kosmos, Ikonos, Alos, QuickBird and Orbview [47]. However, data access collected by satellites, particularly high-resolution data, is still difficult due to prohibitive costs and other restrictions [7]. This situation constrains research objectives especially in developing countries. Nevertheless, in Senegal, the Direction of Geographic and Cartography (DTGC) and the Ecologic Monitoring Centre (CSE) often provide remote sensing data to researcher in relation with their study areas. For researchers, the use of data providing by national institution such DTGC and CSE, specializing in geospatial technologies largely ensures (i) the source of the data, (ii) their characteristics, (iii) their quality, and (iv) guaranteed their Rights-of-Use for scientific purposes.

In this study the images have been chosen based on their availability, their date of acquisition, their spatial resolution (quality), their right-of-use, the socio-economic and the 
environmental context. Based on these criteria, four different image sources have been selected: two aerial photographs and two satellite images. This study aims therefore at evaluating the potential of multisource remote sensing data for mapping LULC changes in Somone coastal lagoon from 1950 s to 2000 s. In this context, the main problem to be solved is related to the accuracy assessment of ancient classification maps, due to the low mapping coverage. It was important to consider the accuracy of classifications in all studies of change detection, because it has an impact on change results. Overall, the results obtained in this study are very significant and allowed production and analysis of LULCCs.

The following section provides a brief description of the study areas and datasets, then a detailed description of the methodological approach and results. Finally, a discussion of methodology and results, and a conclusion are presented in the last section.

Study area

Somone coastal lagoon is geographically located between latitude $14^{\circ} 23^{\prime} 27^{\prime \prime} \mathrm{N}$ and longitude $16^{\circ} 57^{\prime} 17^{\prime \prime} \mathrm{W}$ [48], $77 \mathrm{~km}$ south of Dakar in Senegal. It is bounded to the west by the Atlantic Ocean, to the north by the cliffs of Thiès, to the east and south by Nguékhokh plain. It is part of the RNICS (Somone Natural Reserve of Communal Interest) of about $7 \mathrm{~km}^{2}$ (700ha), established in 1999. The RNICS encompasses three rural settlements: Guereo, Thiafoura and Sorokhassap (Sindia) and the commune of Somone, all located in the region of Thies. Until its creation in 2008, Somone was part of Sindia commune. Its vegetation is mainly mangrove, which dominates the lagoon area. The climate is tropical Sahelo-Sudanian, characterized by two contrasting annual seasons: a long dry, extremely hot season from November to May and a warm and short humid rainy season from June to October. Total annual rainfall is estimated at $760 \mathrm{~mm}$ at the Mbour station. Maximum monthly precipitation of $400 \mathrm{~mm}$ is recorded in August. Monthly average temperature is $27.31^{\circ} \mathrm{C}$. The highest temperature of $36.5^{\circ} \mathrm{C}$ was recorded in April and lowest temperature of $15^{\circ} \mathrm{C}$ is recorded either in December, January or February. The dry season is characterised by the predominance of the trade wind, with a high relative humidity of $60 \%$. The rainy season is dominated by south-west monsoon that flows from the St. Helena high. Air humidity is high with a maximum of $96 \%$ in August and September [49].
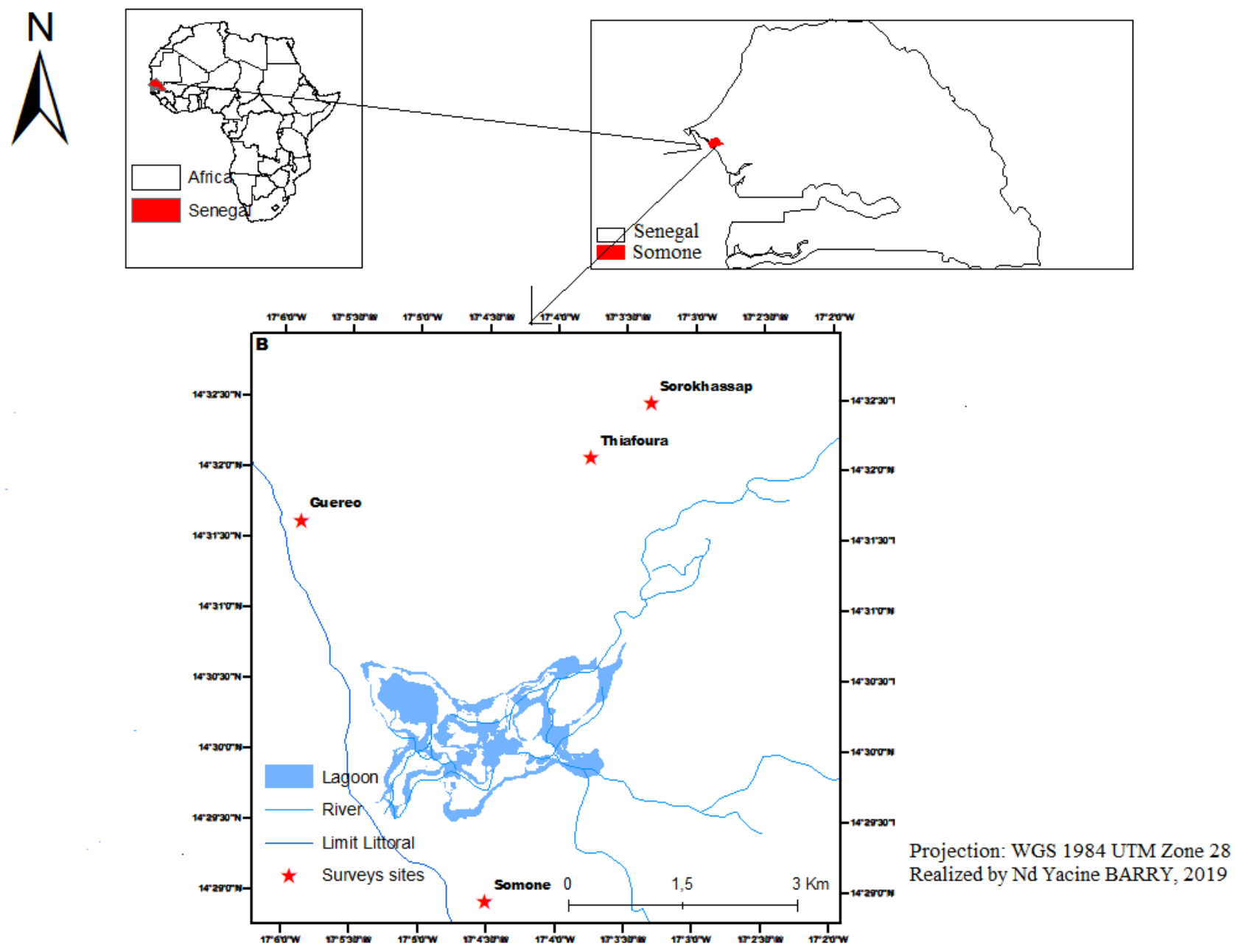

Figure 1. Situation of the study area. 
The data set used for this present study included two aerial photographs, recorded in January 1954 and February 1978. The source of these data is National Geographic Institute (IGN) and were acquired from the Geographic and Cartographic Direction s. In addition, there were two satellite images, QuickBird and GeoEye recorded respectively in 2003 and 2016. The image' characteristics are given in table 1 .

Table 1. Data sources and their characteristics.

\begin{tabular}{llll}
\hline Data type & Date & Bands & Acquisition source \\
\hline Aerial photos & 1954 & Panchromatic & DTGC \\
Aerial photos & 1978 & Panchromatic & DTGC \\
Quickbird & 2003 & $1,2,3 \& 4$ & DTGC \\
Geoeye & 2016 & $1,2 \& 3$ & Google earth \\
\hline
\end{tabular}

\section{Materials and Methods}

Several methods have been applied in this study namely: data pre-processing, segmentation, classification and accuracy assessment, changes detection, no change/change accuracy assessment, and analysis of results (Figure 1).

\subsection{Image Pre-processing}

In order to avoid false inferences, the images obtained were geometrically corrected and geocoded $[50,51]$ to the Universal Transverse Mercator (UTM) coordinate system through a reference image. Geometric correction of the imagery was performed by rectifying all images to 2016 base imagery (GeoEye), which had been rectified previously to $\sim 0.4$ pixel by $\sim 20$ ground control points (GCPs) obtained with GPS from the first fieldwork mission. Images were linearly transformed, and a nearest-neighbour resampling algorithm was used to avoid modification of radiometric values. The root means square (RMS) error values associated with each registration were less than 0.5 pixel indicating that the image was accurate within one pixel.

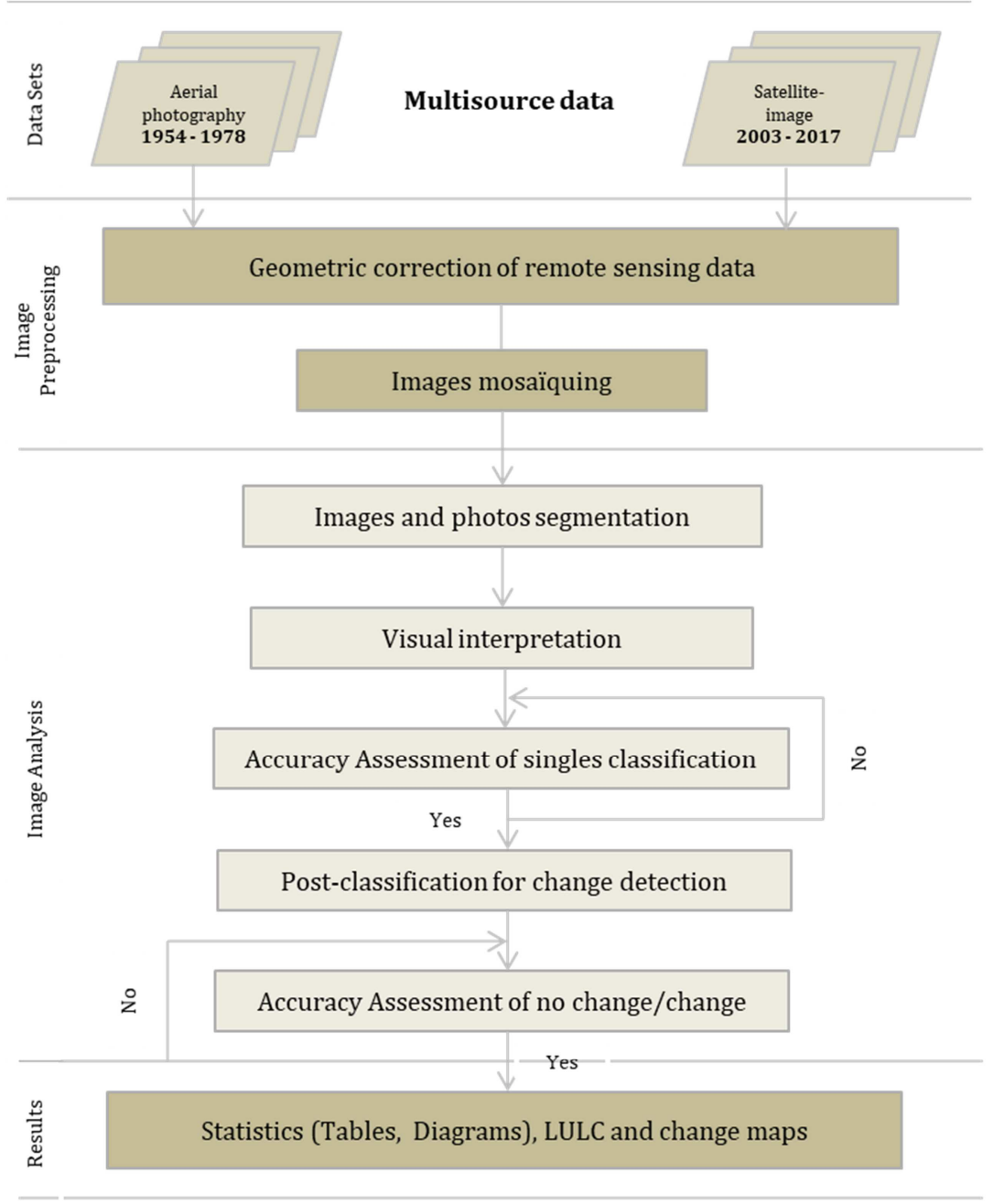

Figure 2. General framework of the study.

\subsection{Image Classification}

There are two basic methods for the extraction of LCLU information from satellite based remotely sensed data [52]. Those are visual interpretations of the images from a computer screen and computer-based processing using the 
actual digital numbers collected by the satellite sensor and appropriate image analysis software [53, 54]. The approach of choice depends on the purpose, nature and characteristics of the data, the data quality, the size of the study area and the time required to return the mapping information [55]. In this study, visual interpretation assisted by computer method, was chosen, because of the heterogeneity of data sources, the spatial and spectral resolutions, the quality defects noted mainly in aerial photography and the small size of the study area.

In addition, visual interpretation is still one of the most widely used methods for detecting, identifying and characterizing the land features on an image since human brain is a good interpreter of images [56]. Some classes were spectrally confused and could not be separated well, using supervised classification. Therefore, visual interpretation was required to separate classes [57]. The interpretation of satellite imagery and aerial photographs involves the analysis of various basic parameters of an object with reference to spectral bands, which is useful in visual analysis. The basic elements included shape, size, pattern, tone, texture, shadows, location, association and resolution [58]. Advances in computer, GIS and remote sensing technology offer new possibilities for managing, editing and generating raster and vector data, facilitating the visual interpretation methods [59]. To facilitate the images classification by computerassisted visual interpretation, the images are first segmented into homogeneous regions. Image segmentation is based on the radiometric (for aerial photographs in panchromatic mode) or spectral (for multispectral images), geometric and similar textural properties of pixels, to merge them into homogeneous object classes, using a bottom-up growth technique for regions $[60,61]$. The results of the segmentation were converted into shapefiles prior to visual interpretation. The shapefiles were manually merged according to the classes identified in order to obtain information on the land use land cover in Somone coastal lagoon.

Table 2. Description of the informative classes adopted for land use/cover maps.

\begin{tabular}{ll}
\hline LCLU class & Description \\
\hline $\begin{array}{l}\text { Cropland } \\
\text { Tidal areas }\end{array}$ & $\begin{array}{l}\text { This class is applicable to cultivable land and cultivated land, and also to agroforestry areas. } \\
\text { Areas regularly flooded during high tide or during rainy season. } \\
\text { Coastal lagoons are inland water bodies, found on all continents, usually oriented parallel to the coast, separated from the ocean by } \\
\text { a barrier, connected to the ocean by one or more restricted inlets which remain open at least intermittently, and have water depths } \\
\text { which seldom exceed a few meters. }\end{array}$ \\
Mangrove, shrubs and trees mainly belonging to the families Rhizophoraceae, Acanthaceae, Lythraceae, Combretaceae and \\
Mangrove & Arecaceae; grow in thickets or dense forests along tidal estuaries, salt marshes and muddy coasts. \\
Sabkha & Sabkha is an Arabic name for a salt-flat ordinarily found nearby sand dunes. land saline areas devoid of vegetation \\
Somone river & Water body which extends about ten (10) km between the bridge on the national road and the lagoon. \\
Vegetated sabkha & Saline area where can growth species namely: Sesuvium portulacastrum, Philoxerus vermicularis, Paspalum vaginatum, \\
Heleocharis mutata, Heleocharis Salinis, Scirpus maritimus, Sporobolus robustus, Salmonella, Phytophthora. & \\
Bare Soil & Land areas of exposed soil surface as influenced by human impacts and/or natural causes. It contains sparse vegetation with very \\
Forest area & low plant cover value as a result of overgrazing, woodcutting, etc. \\
Settlements & Forest area is considered in this study as natural vegetation such as woody and herbaceous species. \\
Beach & Include habitats, hostels, residences that are built in the lagoon's surroundings \\
& The areas of sand, shingle and larger stones.
\end{tabular}

\subsection{Accuracy Assessment of Classification Results}

Accuracy assessment is very important for determining the quality and reliability of results and the uncertainty information derived from remotely sensed data [62]. It is the procedure used to compare the classification results to the geographical reference data that are assumed to be corrected $[16,63]$. It is necessary to pay attention to the classification in the land use monitoring, studies using the postclassification comparison method, where the classification error will affect the accuracy of the change detection results [64]. Field data, high resolution images or existing maps are commonly used to assess the quality of the classification results produced from any imagery source [63, 65], to generate an error matrix and accuracy measures for each land-use/land-cover map [66]. To assess the accuracy of the recent classification, field truth points were collected in the study area following two field missions organized in January and November 2016, using a handheld Garmin Global Positioning System. Reference points were collected, based on stratified random sampling. A total of 300 Ground truth points was selected, with 30 points from each class. Data reference were compared with the classified map of 2014. To evaluate the user's and the producer's accuracy, an error matrix was applied, to compare the relationship between the classified map and the reference data [67]. The overall accuracy (Equation 1) and the Kappa coefficient (Equation 2) were used for accuracy assessment and they are calculated following the formulas:

$$
P=\frac{1}{n} \sum_{i=1}^{n} P_{i c}
$$

Where $\mathrm{n}$ is the total number of pixels included in the matrix.

$$
K=\frac{N \sum_{i=1}^{r} x_{i i}-\sum_{i=1}^{r}\left(x_{i+*} * x_{+i}\right)}{N^{2}-\sum_{i=1}^{r}\left(x_{i+*} * x_{+i}\right)}
$$

Where $r$ is the number of rows in the matrix, $x_{i i}$ is the number of observations in row $\mathrm{i}$ and column i (i.e., diagonal element, $x_{i+}$ and $x_{+i}$ are the marginal totals of rows $i$ and column $i$, respectively, and $N$ is the total number of sites of the matrix [66]. According to [68] Kappa coefficient varies 
between 0 to 1 .

Due to the lack of appropriate map data available in the study area, an intermediate solution which is the manual selection by neutral experts of reference data collected directly on the different satellite images and aerial photos, was used.

Therefore, based on the stratified sampling, experts randomly selected 300 points (30 points from each class) to evaluate the precision of the 1954, 1978, 1990 and 2003 classification images. The confrontation of reference points, using equations 1 and 2, allowed the realization of confusion matrices. The overall accuracy of a classification was then expressed as the sum of the points whose land use is correct divided by the total number of points [69]. It corresponds to the ratio between the number of individuals (or pixels) ranked well, the total number of individuals.

\subsection{Land Use Land Cover Change Detection}

Using remote sensing techniques, LULC changes are mapped by detecting the differences in the satellite's images of different periods with appropriate change detection methods $[9-11,13,16]$. The overview and the repeatability satellite remote sensing can provide timely, accurate and consistent information about earth's surface for cost- and time-efficient monitoring for environmental changes [70-72]. This information is critical to the management of natural resources, the conservation of ecosystems and biodiversity as well as decision support for sustainable development [21]. In the last four decades, the development of change detection techniques has made considerable progresses, as shown in previous literature reviews [12]. The type of method used to determine land use land cover changes may have important effects on qualitative and quantitative results [65]. Among the existing methods, the post-classification comparison approach has been used. This direct approach is not very sensitive to the difference in the dates acquisition of images, the poor quality of the geometric corrections and the quality of the change pixels [71]. This method has been considered as the most appropriate method for this study. It therefore consisted of the classification of each image in the multitemporal dataset independently, using the same classification scheme. The detailed from-to change information can be then extracted by comparing the classified images on a pixel-by pixel basis [14]. One of the main advantages of this approach is that it generates a transition matrix. This is the only method in which "from" and "to" classes can be calculated for each changed feature of the study area. The main advantage of this method is to easily create and update GIS databases, as quantitative values of class/categories are given and manage [68]. The classification results were compared to generate a change matrix and measure changes in land use land cover changes. This matrix provides essential information about the nature and spatial distribution of changes [69]. Then, the change in LULC was analysed to underline gains and losses [70], for the four time periods.

\subsection{Accuracy Assessment of Change Results}

In order to assess change results, a quantitative method was applied. This approach is proposed by [71], based on the modification of error matrix for the classification of a single date. The single classification error matrices, unchanged/changed matrices present the classes identified by Remote Sensing on one axis and on the other axis their correspondence in the field (omission and commission error); while the diagonal matrices indicate a correct classification [72]. The change detection error matrices were simplified by collapsing into unchanged/changed error matrices: the upper left returns areas that have stay the same in the classification or reference data; the upper right box indicates areas, where classification has not detected a change and the reference data considered have been modified. This information is useful to guide the problems analysis in the classification from the change detection error matrix and the error matrix without change of change. The user can determine whether poor accuracy is due to poor change detection technique, poor classification, or both [73]. Therefore, if the accuracy in the unchanged/changed matrix increases significantly over the full change-detection error matrix, the general change is being detected but not the within exact classes. If the two matrices produce similar accuracies, the general changes are not being detected [74]. To generate the error matrix, the same points used to validate the classification have been applied. Overall accuracy and Kappa index are calculated using equation 1 and 2 for the periods 1954-1978, 1978-2003 and 2003-2016.

\section{Results}

LULC classification and their changes were analysed in Somone coastal lagoon for the years 1954, 1978, 2003 and 2016, using multisource remote sensing data,

\subsection{Land Use and Land Cover Classification}

The classification was proceeded using the visual interpretation assisted by computer approach. The eleven identified classes were crop land, tidal areas, lagoon, mangrove, forest area, sabkha, Somone river, vegetated sabkha, bare soil, settlements and beach. The classification results were validated by the ground truth data collected, during a field mission, basing on participatory mapping. Images were checked using a stratified random sampling method including a minimum of 300 points, with at least 30 points for each class. Error matrices were constructed, in this fact, to compare the class identified for each reference data randomly selected with the class assigned to these reference data. An error matrix is a very effective way to represent map accuracy, because the individual accuracy of each category is widely described with the errors of both inclusion (commission errors) and exclusion (omission errors) within the classification [68]. Overall, user's and producer's accuracies and kappa coefficient were derived from the error matrices (Tables 3-6). 
Table 3. Classification accuracy results for 1954 photographer data derived map.

\begin{tabular}{|c|c|c|c|c|c|c|c|c|c|c|c|c|}
\hline \multirow{2}{*}{$\begin{array}{l}\text { Classified } \\
\text { data }\end{array}$} & \multicolumn{10}{|c|}{ Reference data } & \multirow{2}{*}{$\begin{array}{l}\text { Producers } \\
\text { Accuracy (\%) }\end{array}$} & \multirow{2}{*}{$\begin{array}{l}\text { User's } \\
\text { accuracy (\%) }\end{array}$} \\
\hline & 1 & 2 & 3 & 4 & 5 & 6 & 7 & 8 & 9 & 10 & & \\
\hline 1 & 70 & 17.50 & 0 & 5.41 & 18.92 & 0 & 11.11 & 10.53 & 10 & 10.34 & 70.20 & 41.18 \\
\hline 2 & 16.67 & 57.50 & 0 & 0 & 0 & 6.06 & 8.33 & 7.89 & 6.67 & 6.90 & 57.50 & 57.50 \\
\hline 3 & 0 & 0 & 62.50 & 5.41 & 0 & 0 & 0 & 0 & 0 & 0 & 62.50 & 90.91 \\
\hline 4 & 0 & 2.50 & 15.63 & 70.27 & 8.11 & 0 & 0 & 0 & 6.67 & 0 & 70.27 & 70.27 \\
\hline 5 & 0 & 7.50 & 15.63 & 8.11 & 64.86 & 0 & 0 & 0 & 0 & 0 & 64.86 & 68.57 \\
\hline 6 & 3.33 & 0 & 0 & 0 & 0 & 72.73 & 5.56 & 7.89 & 0 & 0 & 72.73 & 80.15 \\
\hline 7 & 0 & 0 & 0 & 0 & 0 & 12.12 & 72.22 & 7.89 & 0 & 0 & 72.22 & 78.79 \\
\hline 8 & 3.33 & 5.00 & 0 & 0 & 0 & 0 & 2.78 & 65.79 & 3.33 & 10.34 & 65.79 & 75.76 \\
\hline 9 & 6.67 & 10 & 6.25 & 10.81 & 8.11 & 9.09 & 0 & 0 & 73.33 & 0 & 73.33 & 55.00 \\
\hline 10 & 0 & 0 & 0 & 0 & 0 & 0 & 0 & 0 & 0 & 72.41 & 72.41 & 100.00 \\
\hline
\end{tabular}

The estimated value of Kappa is 0.64 . Percentage accuracy is 67.83 per cent.

1—Crop land; 2-Tidal areas; 3-Lagoon; 4-Mangrove; 5-Sabkha; 6-Somone river; 7—Vegetated sabkha; 8—Forest areas; 9-Settlements; 10-Beach.

Table 4. Classification accuracy results for 1978 photographer data derived map.

\begin{tabular}{|c|c|c|c|c|c|c|c|c|c|c|c|c|}
\hline \multirow{2}{*}{$\begin{array}{l}\text { Classified } \\
\text { data }\end{array}$} & \multicolumn{10}{|c|}{ Reference data } & \multirow{2}{*}{$\begin{array}{l}\text { Producers } \\
\text { Accuracy (\%) }\end{array}$} & \multirow{2}{*}{$\begin{array}{l}\text { User's } \\
\text { accuracy (\%) }\end{array}$} \\
\hline & 1 & 2 & 3 & 4 & 5 & 6 & 7 & 8 & 9 & 10 & & \\
\hline 1 & 73.33 & 3.23 & 0 & 0 & 10 & 8.33 & 9.09 & 5.41 & 3.23 & 10.34 & 73.33 & 57.89 \\
\hline 2 & 13.33 & 74.19 & 0 & 0 & 6.67 & 8.33 & 6.06 & 2.70 & 0 & 6.90 & 74.19 & 62.16 \\
\hline 3 & 0 & 0 & 70.59 & 0 & 0 & 0 & 0 & 0 & 0 & 0 & 70.59 & 100.00 \\
\hline 4 & 3.33 & 0 & 8.82 & 67.57 & 6.67 & 0 & 0 & 0 & 0 & 0 & 67.57 & 80.65 \\
\hline 5 & 3.33 & 9.68 & 5.88 & 8.11 & 73.33 & 8.33 & 3.03 & 2.70 & 3.23 & 0 & 73.33 & 59.46 \\
\hline 6 & 0 & 0 & 5.88 & 8.11 & 0 & 75.00 & 3.03 & 0 & 0 & 0 & 75.00 & 81.82 \\
\hline 7 & 6.67 & 6.45 & 8.82 & 10.81 & 0 & 0 & 72.73 & 13.51 & 19.35 & 0 & 72.73 & 52.17 \\
\hline 8 & 0 & 0 & 0 & 0 & 0 & 0 & 0 & 75.68 & 0 & 0 & 75.68 & 100.00 \\
\hline 9 & 0 & 6.45 & 0 & 5.41 & 3.33 & 0 & 6.06 & 0 & 70.97 & 10.34 & 70.97 & 68.75 \\
\hline 10 & 0 & 0 & 0 & 0 & 0 & 0 & 0 & 0 & 3.23 & 72.41 & 72.41 & 95.45 \\
\hline
\end{tabular}

The estimated value of Kappa is 0.69 . Percentage accuracy is 72.56 per cent.

1-Crop land; 2-Tidal areas; 3-Lagoon; 4-Mangrove; 5-Sabkha; 6-Somone river; 7—Vegetated sabkha; 8—Forest areas; 9-Settlements; 10—Beach.

Table 5. Classification accuracy results for 2003 satellite image derived map.

\begin{tabular}{|c|c|c|c|c|c|c|c|c|c|c|c|c|c|}
\hline \multirow{2}{*}{$\begin{array}{l}\text { Classified } \\
\text { data }\end{array}$} & \multicolumn{11}{|c|}{ Reference data } & \multirow{2}{*}{$\begin{array}{l}\text { Producers } \\
\text { Accuracy (\%) }\end{array}$} & \multirow{2}{*}{$\begin{array}{l}\text { User's } \\
\text { accuracy (\%) }\end{array}$} \\
\hline & 1 & 2 & 3 & 4 & 5 & 6 & 7 & 8 & 9 & 10 & 11 & & \\
\hline 1 & 81.58 & 5.71 & 0 & 5.56 & 9.38 & 0 & 5.71 & 6.45 & 10.53 & 0 & 7.14 & 81.58 & 64.58 \\
\hline 2 & 7.89 & 80 & 2.94 & 0 & 6.25 & 0 & 0 & 9.68 & 0 & 0 & 0 & 80.00 & 75.68 \\
\hline 3 & 0 & 0 & 85.29 & 0 & 0 & 5.71 & 0 & 0 & 0 & 0 & 0 & 85.29 & 93.55 \\
\hline 4 & 0 & 0 & 0 & 86.11 & 0 & 2.86 & 0 & 0 & 5.26 & 0 & 0 & 86.11 & 91.18 \\
\hline 5 & 2.63 & 11.43 & 2.94 & 5.56 & 84.38 & 2.86 & 5.71 & 6.45 & 0 & 0 & 7.14 & 84.38 & 64.29 \\
\hline 6 & 0 & 0 & 8.82 & 0 & 0 & 85.71 & 0 & 0 & 0 & 0 & 3.57 & 85.71 & 88.24 \\
\hline 7 & 0 & 0 & 0 & 2.78 & 0 & 0 & 82.86 & 0 & 5.26 & 8.33 & 0 & 82.86 & 82.86 \\
\hline 8 & 7.89 & 2.86 & 0 & 0 & 0 & 2.86 & 5.71 & 77.42 & 0 & 0 & 0 & 77.42 & 77.42 \\
\hline 9 & 0 & 0 & 0 & 0 & 0 & 0 & 0 & 0 & 78.95 & 0 & 0 & 78.95 & 100.00 \\
\hline 10 & 0 & 0 & 0 & 0 & 0 & 0 & 0 & 0 & 0 & 91.67 & 3.57 & 91.67 & 97.06 \\
\hline 11 & 0 & 0 & 0 & 0 & 0 & 0 & 0 & 0 & 0 & 0 & 78.57 & 78.57 & 100.00 \\
\hline
\end{tabular}

The estimated value of Kappa is 0.81 . Percentage accuracy is 83.07 per cent.

1-Crop land; 2-Tidal areas; 3-Lagoon; 4-Mangrove; 5-Sabkha; 6-Somone river; 7-Vegetated sabkha; 8-Bare land; 9-Forest areas; 10Settlements; 11-Beach.

Table 6. Classification accuracy results for 2016 satellite image derived map.

\begin{tabular}{|c|c|c|c|c|c|c|c|c|c|c|c|c|c|}
\hline \multirow{2}{*}{$\begin{array}{l}\text { Classified } \\
\text { data }\end{array}$} & \multicolumn{11}{|c|}{ Reference data } & \multirow{2}{*}{$\begin{array}{l}\text { Producers } \\
\text { Accuracy (\%) }\end{array}$} & \multirow{2}{*}{$\begin{array}{l}\text { User's } \\
\text { accuracy }(\%)\end{array}$} \\
\hline & 1 & 2 & 3 & 4 & 5 & 6 & 7 & 8 & 9 & 10 & 11 & & \\
\hline 1 & 91.18 & 9.09 & 0 & 0 & 3.33 & 0 & 0 & 2.78 & 5.26 & 0 & 6.45 & 91.18 & 77.50 \\
\hline 2 & 2.94 & 87.88 & 0 & 0 & 3.33 & 0 & 0 & 5.56 & 0 & 0 & 0 & 87.88 & 87.88 \\
\hline 3 & 0 & 0 & 97.06 & 0 & 0 & 3.23 & 0 & 0 & 0 & 0 & 0 & 97.06 & 97.06 \\
\hline 4 & 0 & 0 & 0 & 94.44 & 0 & 0 & 0 & 0 & 0 & 0 & 0 & 94.44 & 100.00 \\
\hline
\end{tabular}




\begin{tabular}{|c|c|c|c|c|c|c|c|c|c|c|c|c|c|}
\hline \multirow{2}{*}{$\begin{array}{l}\text { Classified } \\
\text { data }\end{array}$} & \multicolumn{11}{|c|}{ Reference data } & \multirow{2}{*}{$\begin{array}{l}\text { Producers } \\
\text { Accuracy (\%) }\end{array}$} & \multirow{2}{*}{$\begin{array}{l}\text { User's } \\
\text { accuracy (\%) }\end{array}$} \\
\hline & 1 & 2 & 3 & 4 & 5 & 6 & 7 & 8 & 9 & 10 & 11 & & \\
\hline 5 & 0 & 3.03 & 0 & 2.78 & 93.33 & 0 & 3.03 & 0 & 0 & 0 & 0 & 93.33 & 90.32 \\
\hline 6 & 0 & 0 & 2.94 & 0 & 0 & 93.55 & 0 & 0 & 0 & 0 & 0 & 93.55 & 96.67 \\
\hline 7 & 0 & 0 & 0 & 2.78 & 0 & 0 & 96.97 & 0 & 5.26 & 0 & 0 & 96.97 & 91.43 \\
\hline 8 & 5.88 & 0 & 0 & 0 & 0 & 3.23 & 0 & 91.67 & 0 & 0 & 0 & 91.67 & 91.67 \\
\hline 9 & 0 & 0 & 0 & 0 & 0 & 0 & 0 & 0 & 89.47 & 0 & 0 & 89.47 & 100.00 \\
\hline 11 & 0 & 0 & 0 & 0 & 0 & 0 & 0 & 0 & 0 & 0 & 90.32 & 90.32 & 100.00 \\
\hline
\end{tabular}

The estimated value of Kappa is 0.92 . Percentage accuracy is 93.15 per cent.

1-Crop land; 2-Tidal areas; 3-Lagoon; 4-Mangrove; 5-Sabkha; 6-Somone river; 7-Vegetated sabkha; 8-Bare soil; 9-Forest areas; 10Settlements; $11-$ Beach.

Image accuracy tended to improve as the image date becomes more recent [75]. This is due to the improvement in processes for acquiring aerial photographs and satellite images, as well the methods for extracting information from remote sensing data. In addition, there are the conservation defects most often noted with aerial photographs, which usually lead to the alteration of the radiometric value of photographs. The overall accuracy of multisource classification of this study was $67.83 \%$ for $1954,72.56 \%$ for $1978,83.07 \%$ for 2003 and $93.15 \%$ for 2016 . The Kappa coefficient of multisource classification was 0.64 for 1954, 0.69 for 1978, 0.81 for 2003 and 0.92 for 2016 (Tables 3-6). The user's and producer's accuracies of individual classes constantly vary within the year and according to the type of image. In 1954, the tidal areas class had the lowest producer's accuracy (i.e. $57.50 \%$ ), because some tidal class in the study area was misclassified as crop land. In 1978, vegetated sabkha map was the least accurate (i.e. 52.17\%) among the ten covers (Table 4). Among the reference data associated to vegetated sabkha class, $19.35 \%$ represent settlements, $13 \%$ forest area, $10.81 \%$ mangrove, $8.82 \%$ lagoon and $\sim 6.50 \%$, both crop land and tidal area. These errors are mainly attributed to the radiometry often close to the aerial photographs. Consequently, it was difficult to distinguish them accurately. In 2003, the bare soil class had the lowest producer's accuracy (i.e. $77.42 \%$ ) (Table 5). Some of this class was misclassified as crop land, tidal area and sabkha. These errors could be related to the difficulties of visually separating these classes during the dry season when the shooting was done. Finally, in 2016, tidal area is mapped with an accuracy of $87.88 \%$, the second lowest among the eleven classes of LULC and $1.59 \%$ lower than of forest area (Table 6). Generally, the lagoon, settlements and the large area such as cropland and mangrove etc.), have a better Producers Accuracy and User's accuracy. The classification results have attar Kappa for all processed data [76]. Figure 2 shows the classification results of multisource data for 1954, 1978, 2003 and 2016. The aerial photographer of March 1954 shows the percentage area for crop land, $31.61 \%$, tidal area, $1.78 \%$, lagoon, $3.67 \%$, mangrove, $4.07 \%$, sabkha, $5.29 \%$, Somone river, $0.38 \%$, settlements, $0.29 \%$ and beach $1.85 \%$.
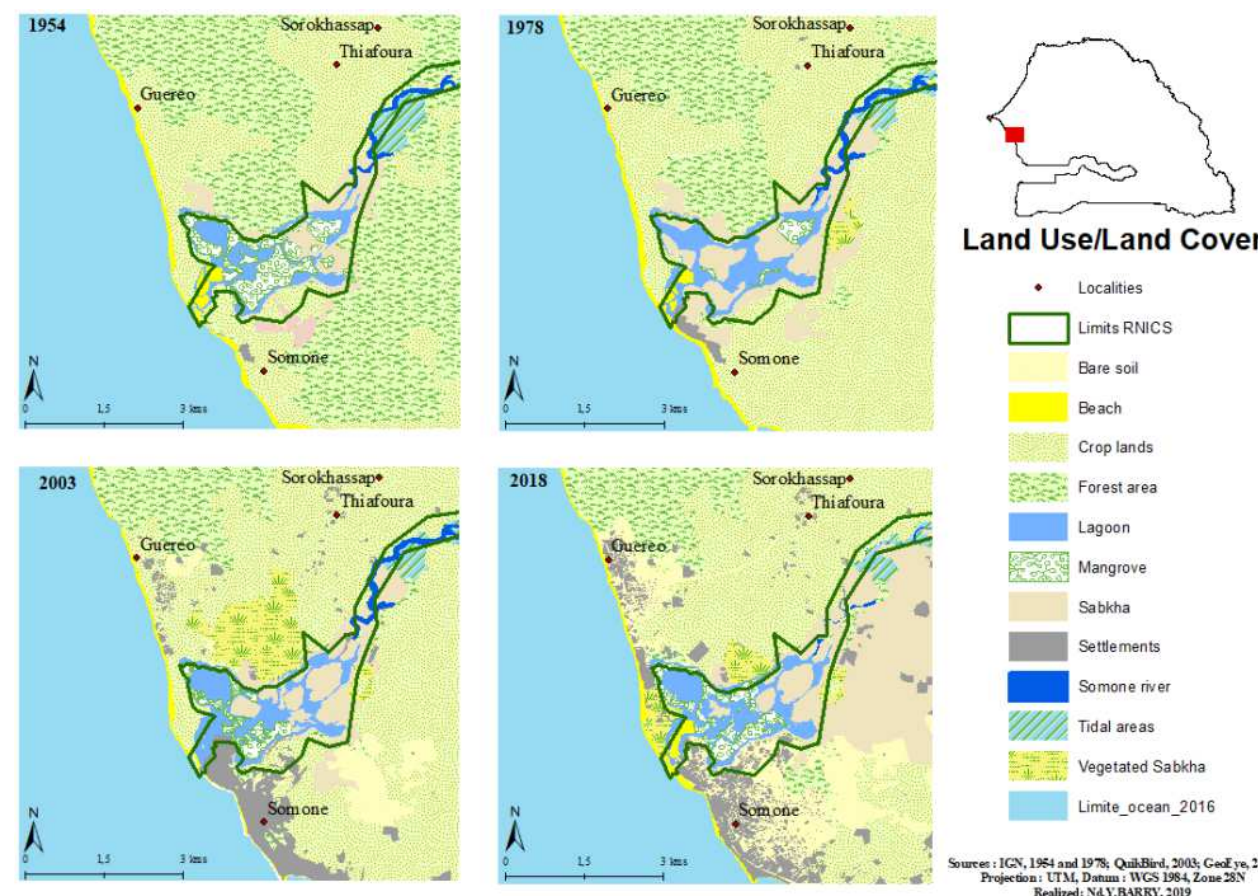

Land Use/Land Cover

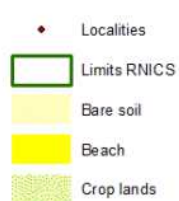

Baxizest Forest area
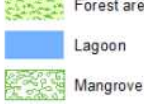

Sabkha

Sabkha
Settlements

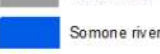

VVID. Tidal areas

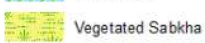

Limite_ocean_2016

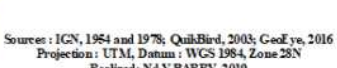

Figure 3. Land use and land cover classification map of the Somone coastal lagoon during the years 1954; 1978; 2003 and 2016. 


\subsection{Land Use and Land Cover Change}

This study aimed at estimating and assess the amount of changes in LULC in Somone coastal lagoons. Therefore, based on the results of multisource classification, postclassification comparison change detection was calculated to determine changes types during the 63-year period. Postclassification comparison approach was assessed using a minimum of 300 ground truth points during the time periods 1954-1978, 1978-2003 and 2003-2016. Change detection error matrix [77] was selected to evaluate change results. The change detection error matrices were simplified by collapsing into non-change/change error matrices: the upper left area returns areas that have not changed in the classification or reference data; the upper right box indicates areas where classification has not detected a change and the reference data considered have been modified. Average accuracy from the change of all predefined classes were used and classes were merged as 'unchanged' and 'changed' super-classes. Overall accuracy can be calculated by adding the true change (change/change) and true no-change (unchanged/unchanged) percentage [78] in table 7. Broadly, the change matrices showed a good performance resulting to the comparison of change results with reference data. Overall, an accuracy of $66 \%$ for $1954-$ 1978 LULC change detection, $72.7 \%$ for $1978-2003$ and $80.6 \%$ for $2003-2016$ were observed.

Table 7. No-change/change error matrices between 1954-1978, 1978-2003 and 2003-2016.

\begin{tabular}{|c|c|c|c|c|c|c|c|c|c|c|c|}
\hline \multicolumn{3}{|c|}{ 1954-1978 } & \multicolumn{4}{|c|}{ 1978-2003 } & \multicolumn{4}{|c|}{ 2003-2016 } & \multirow[b]{2}{*}{ Total } \\
\hline & $\mathbf{N C}$ & $\mathbf{C}$ & Total & & NC & $\mathbf{C}$ & Total & & NC & $\mathbf{C}$ & \\
\hline $\mathrm{NC}$ & 56,33 & 22 & 78,33 & $\mathrm{NC}$ & 67,58 & 16,97 & 84,55 & $\mathrm{NC}$ & 74,85 & 12,42 & 87,27 \\
\hline $\mathrm{C}$ & 12 & 9,67 & 21,67 & $\mathrm{C}$ & 10,30 & 5,15 & 15,45 & $\mathrm{C}$ & 6,97 & 5,76 & 12,73 \\
\hline Total & 68,33 & 31,67 & 100 & Total & 77,88 & 22,12 & 100 & Total & 81,82 & 18,18 & 100 \\
\hline \multicolumn{4}{|c|}{ Overall accuracy $66 \%$} & \multicolumn{4}{|c|}{ Overall accuracy $72.7 \%$} & \multicolumn{4}{|c|}{ Overall accuracy $80.6 \%$} \\
\hline
\end{tabular}

$\mathrm{NC}=$ No-change $(\%) ; \mathrm{C}=$ Change $(\%)$.

The individual classes for multisource classification results are summarized in Table 8, and the change statistics between 1954 to 2016 are shown in figure 3. Forest area was the main land cover in 1954 with $51.06 \%$ of study area, followed by crop land (31.61\%), Sabkha (5.29\%), mangrove (4.07) lagoon (3.67\%), tidal areas and settlements with an area close to $2 \%$ and the other classes less than $1 \%$. The forest area decreased from $51.06 \%\left(22.53 \mathrm{~km}^{2}\right)$ in 1954 to $10.86 \%$ $\left(4.78 \mathrm{~km}^{2}\right)$ in 2016. Crop land increased from $31.61 \%$ $\left(13.95 \mathrm{~km}^{2}\right)$ in 1954 to $54.95 \%\left(24.75 \mathrm{~km}^{2}\right)$ in 2003 and decreased to $35.16 \%\left(15.47 \mathrm{~km}^{2}\right)$ in 2016 . The sabkha has increased from $5.29 \%\left(2.33 \mathrm{~km}^{2}\right)$ in 1954 to $18.48 \%$ $\left(8.13 \mathrm{~km}^{2}\right)$ in 2016. Mangrove forest decreased from $4.07 \%$ $\left(1.79 \mathrm{~km}^{2}\right)$ in 1954 to $0.56 \%\left(0.25 \mathrm{~km}^{2}\right)$ in 1978 , then it has increased to $1.44 \%\left(0.65 \mathrm{~km}^{2}\right)$ in 2003 and $2.65 \%\left(1.17 \mathrm{~km}^{2}\right)$ in 2016. Between 1954 and 2016, the Somone lagoon increased from $3.67 \%\left(1.62 \mathrm{~km}^{2}\right)$ to $4.63 \%\left(2.04 \mathrm{~km}^{2}\right)$. Tidal areas and settlements progressively increased from $1.78 \%$ and $0.29 \%$ in 1954 to $1.16 \%$ and $9.21 \%$ in 2016 , respectively. The vegetated sabkha increased from $0.81 \%$ $\left(0.36 \mathrm{~km}^{2}\right)$ in 1978 to $2.63 \%\left(1.15 \mathrm{~km}^{2}\right)$ in 2016 . Bare soil increased from $3.02 \%\left(2.24 \mathrm{~km}^{2}\right)$ in 2003 to $10.76 \%$ $\left(5.91 \mathrm{~km}^{2}\right)$ in 2016 .

Table 8. LULC change rate of the Somone lagoon coastal lagoon between 1954 to 2016.

\begin{tabular}{|c|c|c|c|c|c|c|c|c|c|c|c|}
\hline \multirow{2}{*}{ LULC classes } & \multicolumn{2}{|l|}{1954} & \multicolumn{2}{|l|}{1978} & \multicolumn{2}{|l|}{2003} & \multicolumn{2}{|l|}{2016} & \multicolumn{3}{|l|}{ Changes \% } \\
\hline & $\mathbf{k m}^{2}$ & $\%$ & $\mathbf{k m}^{2}$ & $\%$ & $\mathbf{k m}^{2}$ & $\%$ & $\mathbf{k m}^{2}$ & $\%$ & $1954-1978$ & $1978-2003$ & $2003-2016$ \\
\hline Bare soil & $\begin{array}{ll}-- \\
--\end{array}$ & --- & --- & --- & 2.24 & 3.02 & 5.91 & 10.76 & --- & $\begin{array}{ll}-- \\
--\end{array}$ & 7.74 \\
\hline Beach & 0.82 & 1.85 & 0.85 & 1.93 & 0.4 & 0.9 & 0.7 & 1.59 & 0.08 & -1.03 & 0.69 \\
\hline Settlements & 0.13 & 0.29 & 0.98 & 2.23 & 3.78 & 8.38 & 4.05 & 9.21 & 1.94 & 6.16 & 0.82 \\
\hline Crop lands & 13.95 & 31.61 & 24.17 & 54.82 & 24.75 & 54.95 & 15.47 & 35.16 & 23.22 & 0.12 & -19.78 \\
\hline Tidal areas & 0.79 & 1.78 & 0.62 & 1.40 & 0.64 & 1.42 & 0.51 & 1.16 & -0.38 & 0.02 & -0.26 \\
\hline Lagoon & 1.62 & 3.67 & 2.08 & 4.72 & 2.26 & 5.01 & 2.04 & 4.63 & 1.05 & 0.29 & -0.38 \\
\hline Sabkha & 2.33 & 5.29 & 5.26 & 11.93 & 3.06 & 6.78 & 8.13 & 18.48 & 6.64 & -5.14 & 11.70 \\
\hline Somone river & 0.17 & 0.38 & 0.08 & 0.17 & 0.05 & 0.12 & 0.08 & 0.19 & -0.21 & -0.05 & 0.13 \\
\hline Vegetated Sabkha & --- & --- & 0.36 & 0.81 & 2.69 & 5.96 & 1.15 & 2.63 & --- & 5.15 & -3.34 \\
\hline Forest area & 22.53 & 51.06 & 9.44 & 21.43 & 4.27 & 9.49 & 4.78 & 10.86 & -29.64 & -11.94 & 1.37 \\
\hline
\end{tabular}

It useful to identify LULC trajectory or conversion through a change matrix from 1954 to 2016 . Tables 9,10 and 11 show the conversion of the land cover using a change matrix for three periods, 1954-1978, 1978-2003 and 2003-2016. The major diagonal of each matrix corresponds to the unchanged pixels. In the first period (1954-1978), there was a major change from Somone river to sabkha $(60.77 \%)$, from vegetated sabkha to crop land $(53.46 \%)$, from tidal areas to
Sabkha $(47.77 \%), 44.27 \%$ of the mangrove was converted into lagoon/mudflat and $42.21 \%$ into sabkha. The most stable classes in this period were: settlements $(98.27 \%)$, followed closely by sabkha (94.91\%), crop land (92.26), beach $(86.59 \%)$ and lagoon (71.92\%). During the second period $1978-2003$, there was also a major change from forest areas to crop land $(29.49 \%)$ and vegetated sabkha $(25.86 \%)$. The Somone river has been converted to settlements by $29.31 \%$. 
The vegetated sabkha has been transformed to crop land with $27.33 \%$. Finally, the beach is converted to lagoon by $24.50 \%$. In the same period, a change from lagoon to mangrove and settlements and from sabkha to crop land and settlements were also observed. The classes most resistant to changes, during the second period were: tidal areas (99.58\%), followed by settlements (95.96\%), crop land (81.37\%), mangrove $(80.58 \%)$, Somone river $(67.60 \%)$ and vegetated sabkha $(61.95 \%)$. In the final matrix (2003-2016), the major changes concern, among other changes, the conversion of the vegetated sabkha to crop land $(24.77 \%)$, the crop land conversion to bare land $(22.49 \%)$, the settlements transformation to bare land (18.88\%), tidal areas replacement by sabkha $(18.87 \%)$ and crop land conversion to bare land $(13.47 \%)$. The most unchanged classes included the beach (98.57\%), forest areas, (97.24\%), mangrove (94.27\%), Somone river $(93.34 \%)$, bare land $(87.10 \%)$ and sabkha $(85.73 \%)$.

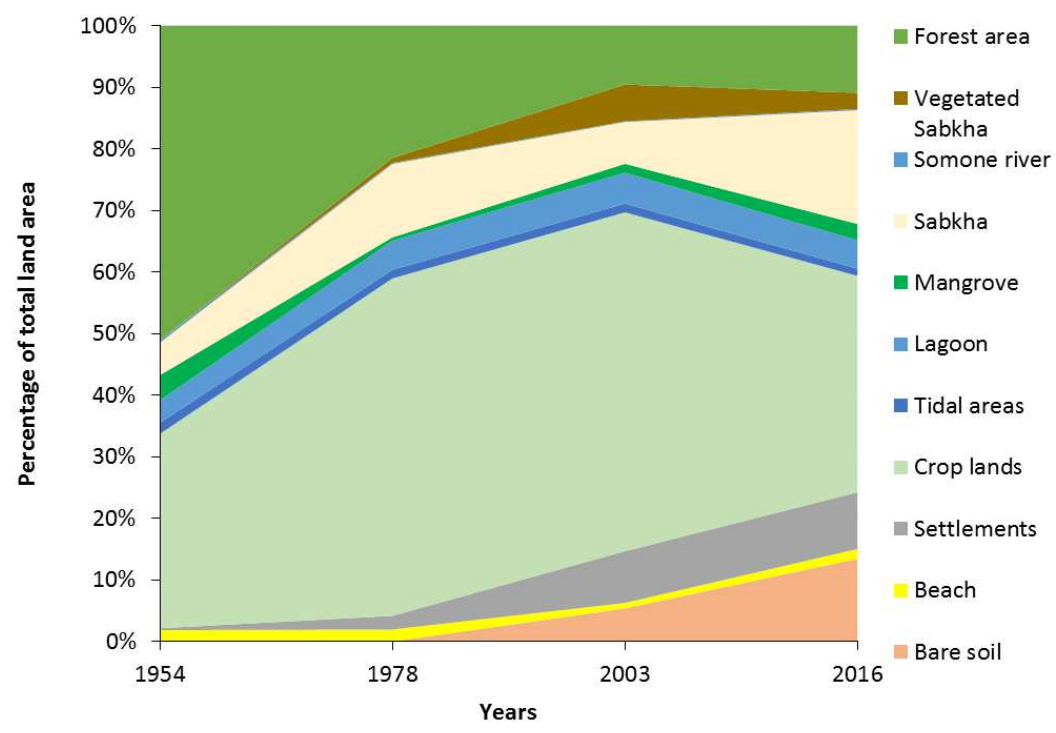

Figure 4. Changes in land-cover classes between 1954 to 2016.

Overall, there was a replacement of natural areas (vegetation cover) and rural areas (crop lands) by man-made areas (settlement/urbanisation), as well the expansion of the Sabkha within the study area. This situation is due to several factors, including the rainfall decreasing over recent decades, settlement development and population growth, tourism sector development salinization of soils (explosion of Sabha), uncontrolled exploitation of natural resources (from 1954 to the 1990s), construction of dams and bridge upstream the Somone river such in the watershed at Bandia (1999) and Kissane (2000), which caused the lagoon silting [77]. This threatens the sustainability of the lagoon and species relating to it such the mangrove, swamp, fish and bird's species [78].

Table 9. Land use and land cover changes matrix between 1954 and 1978.

\begin{tabular}{|c|c|c|c|c|c|c|c|c|c|c|}
\hline \multirow{2}{*}{1978} & \multicolumn{10}{|l|}{1954} \\
\hline & 1 & 2 & 3 & 4 & 5 & 6 & 7 & 8 & 9 & 10 \\
\hline 1 & 92,26 & 0,19 & 0 & 0 & 0,07 & 3,98 & -- & 53,46 & 0,85 & 0,15 \\
\hline 2 & 0 & 50,38 & 0 & 0 & 2,34 & 11,95 & -- & 0,56 & 0,31 & 0,00 \\
\hline 3 & 0,01 & 0 & 71,92 & 44,27 & 0,41 & 0,05 & -- & 0,04 & 0 & 11,96 \\
\hline 4 & 0 & 0 & 0,40 & 13,51 & 0 & 0 & -- & 0 & 0 & 0 \\
\hline 5 & 3,80 & 47,77 & 26,66 & 42,21 & 94,91 & 60,77 & -- & 3,85 & 0,27 & 0,06 \\
\hline 6 & 0,01 & 1,54 & 0 & 0 & 1,43 & 23,21 & -- & 0,02 & 0,04 & 0 \\
\hline 7 & 0 & 0 & 0 & 0 & 0,04 & 0 & -- & 1,58 & 0,12 & 0 \\
\hline 8 & 2,79 & 0,11 & 0 & 0 & 0,05 & 0,05 & -- & 40,29 & 0,15 & 0,44 \\
\hline 9 & 1,13 & 0 & 0,02 & 0 & 0,75 & 0 & -- & 0,19 & 98,27 & 0,80 \\
\hline 10 & 0,01 & 0 & 0,99 & 0,01 & 0,00 & 0 & -- & 0 & 0 & 86,59 \\
\hline Total changes & 7,74 & 49,62 & 28,08 & 86,49 & 5,09 & 76,79 & -- & 67,71 & 1,73 & 13,41 \\
\hline
\end{tabular}

1-Crop land; 2-Tidal areas; 3-Lagoon; 4-Mangrove; 5-Sabha; 6-Somone river; 7—Vegetated sabha; 8-Forest areas; 9-Settlements; 10 -Beach.

Table 10. Land use and land cover changes matrix between 1978 and 2003.

\begin{tabular}{|c|c|c|c|c|c|c|c|c|c|c|c|}
\hline \multirow{2}{*}{2003} & \multicolumn{11}{|l|}{1978} \\
\hline & 1 & 2 & 3 & 4 & 5 & 6 & 7 & 8 & 9 & 10 & 11 \\
\hline 1 & 81,37 & 0,18 & 0 & 0 & 11,70 & 0,29 & 27,33 & -- & 29,49 & 1,24 & 0 \\
\hline 2 & 0,10 & 99,58 & & 0 & 0 & 2,34 & 0 & -- & 0,01 & 0,04 & 0 \\
\hline 3 & 0 & 0 & 68,57 & 3,24 & 13,25 & 0 & 0 & -- & 0 & 0 & 24,50 \\
\hline 4 & 0 & 0 & 15,29 & 80,58 & 5,82 & 0 & 0 & -- & 0 & 0 & 0,71 \\
\hline
\end{tabular}




\begin{tabular}{|c|c|c|c|c|c|c|c|c|c|c|c|}
\hline \multirow{2}{*}{2003} & \multicolumn{11}{|l|}{1978} \\
\hline & 1 & 2 & 3 & 4 & 5 & 6 & 7 & 8 & 9 & 10 & 11 \\
\hline 5 & 0 & 0 & 5,19 & 9,87 & 51,71 & 0,46 & 7,82 & -- & 0 & 0 & 0 \\
\hline 6 & 0 & 0,24 & 0 & 0 & 0 & 67,60 & 0,00 & -- & 0 & 0 & 0 \\
\hline 7 & 0,24 & 0 & 10,37 & 6,31 & 2,08 & 0 & 61,95 & -- & 25,86 & 0 & 0 \\
\hline 8 & 7,96 & 0 & 0 & 0 & 2,46 & 0 & 0 & -- & 1,21 & 1,96 & 0 \\
\hline 9 & 0,29 & 0 & 0 & 0 & 3,08 & 0 & 0 & -- & 42,77 & 0 & 0 \\
\hline 10 & 10,02 & 0 & 0 & 0 & 9,90 & 29,31 & 2,90 & -- & 0,66 & 95,96 & 4,73 \\
\hline 11 & 0,01 & 0 & 0,57 & 0 & 0 & 0 & 0 & -- & 0 & 0,80 & 70,06 \\
\hline Total changes & 18,63 & 0,42 & 31,43 & 19,42 & 48,29 & 32,40 & 38,05 & -- & 57,23 & 4,04 & 29,94 \\
\hline
\end{tabular}

1-Crop land; 2-Tidal areas; 3-Lagoon; 4-Mangrove; 5—Sabha; 6-Somone river; 7—Vegetated sabha; 8—Bare land; 9-Forest areas; 10—Settlements; $11-$ Beach

Table 11. Land use and land cover changes matrix between 2003 and 2016.

\begin{tabular}{|c|c|c|c|c|c|c|c|c|c|c|c|}
\hline \multirow{2}{*}{2016} & \multicolumn{11}{|l|}{2003} \\
\hline & 1 & 2 & 3 & 4 & 5 & 6 & 7 & 8 & 9 & 10 & 11 \\
\hline 1 & 56,43 & 0,26 & 0 & 0 & 0,03 & 1,13 & 24,77 & 1,28 & 0,03 & 2,32 & 0 \\
\hline 2 & 0,01 & 79,45 & 0 & 0 & 0,01 & 4,03 & 0 & 0 & 0 & 0 & 0 \\
\hline 3 & 0,04 & 0 & 79,24 & 5,48 & 5,93 & 0 & 0,33 & 0,65 & 0 & 0,01 & 0,01 \\
\hline 4 & 0 & 0 & 13,52 & 94,27 & 0,05 & 0 & 8,36 & 0,04 & 0 & 0 & 0 \\
\hline 5 & 22,49 & 18,87 & 0,08 & 0 & 85,73 & 1,09 & 0,03 & 0,02 & 0,05 & 0,61 & 0 \\
\hline 6 & 0 & 0,52 & 0 & 0 & 0,04 & 93,34 & 0 & 0 & 0 & 0,76 & 0 \\
\hline 7 & 1,49 & 0 & 0,04 & 0 & 0,01 & 0 & 62,60 & 0 & 0 & 0,01 & 0 \\
\hline 8 & 13,47 & 0 & 0,39 & 0,12 & 0,18 & 0 & 0,90 & 87,10 & 1,77 & 18,88 & 0,01 \\
\hline 9 & 0,72 & 0 & 0 & 0 & 8 & 0 & 0,01 & 7,95 & 97,24 & 0,02 & 0 \\
\hline 10 & 5,27 & 0,90 & 0,02 & 0 & 0,02 & 0,41 & 3 & 2,97 & 0,87 & 76,13 & 1,41 \\
\hline 11 & 0,09 & 0 & 6,70 & 0,14 & 0 & 0 & 0 & 0 & 0,02 & 1,27 & 98,57 \\
\hline Total changes & 43,57 & 20,55 & 20,76 & 0,26 & 14,27 & 6,66 & 37,40 & 12,90 & 2,76 & 23,87 & 1,43 \\
\hline
\end{tabular}

1-Crop land; 2-Tidal areas; 3-Lagoon; 4-Mangrove; 5-Sabha; 6-Somone river; 7-Vegetated Sabha; 8-Bare land; 9-Forest areas; 10Settlements; 11-Beach.

\section{Discussion}

\subsection{Land Use and Land Cover Classification}

Remote sensed data in Somone lagoon has allowed to analyse and understand the changes in land use and cover and therefore provide critical tools for the management of this area. Indeed, the integration of remote sensing data into LULC changes studies is essential for the management of protected areas, especially within coastal lagoons by providing essential information on the nature and spatial distribution of land cover changes. Such in Global trends of change and the effects of the recent establishment of the shrimp aquaculture industry on the natural cover in coastal lagoon system in Mexico [79], describing land cover degradation [80] analysing the LULC changes and associated Ecosystem Services (ESs) of a protected wetland area in the Po river delta (Northern Italy) [81] etc. The aerial photographs have allowed to track LUCCs in Somone 1954 and 1978. These have been the first sources of remote sensing for monitoring LULC changes [4, 82]. Additionally, satellites images (Quickbird and GeoEye) have complemented the LULCs analysis in this study during 2003 and 2016, with an improvement in images quality in term of scales and resolution. There are the satellite images that appeared in the 1970s with the launch of the Landsat satellite into space, thus giving more inputs to the various fields of research. Nowadays, these two sources of spatial information are complementary, particularly on the temporal and spatial dimension: this is called multisource remote sensing. This combination is very useful for monitoring the state of the environment, as it was done in this study in Somone lagoon. These technics indeed offer increasing opportunities for developing countries to consider monitoring and evaluating their natural resources over a long time series. Indeed, some developing countries are facing considerable gaps in mapping coverage on land use change. This situation is explained by the lack of experts or specialists noted in this field, and mostly by the difficulties to access the existing data. Additionally, to the non-affordability in the relevant services and high spatial resolution satellite images. Consequently, many resources or natural spaces are being degraded, without a better understanding of their extent.

\subsection{Land Use and Land Cover Change}

This study showed that Somone coastal lagoon has undergone several land use land cover changes during the last 63 years (1954-2016). Indeed, the mangrove undergone several degrdadation between 1954 and 1978, the forest areas lost more $40 \%$ of its surface between 1954 and 2016 and replaced by Settlements (urbanization) as well as Croplands. Such, coastal lagoons are highly susceptible to human activities, and many now rank among the most heavily impacted aquatic ecosystems on Earth [83-85]. High population density, together with its associated commerce, pollution, and development, will put significant stress on these coastal and near-shore ecosystems [86]. Furthermore, natural resources across globally has been modified by 
human activities such as agriculture, fishery, aquaculture, oysters, arches and others seafood collection, settlements, urbanization, and industrialization. Indeed, human have strong influences on lagoons state and productivity [87]. Over the centuries, coastal lagoons have become foci of settlement, industry, leisure and recreation and have characteristically a rich cultural heritage $[86,88]$. Coastal lagoons support a rich specific biodiversity, and host of different groups of organisms, like plants, animals or microbes [88]. Such human being had transformed the earth, reshaped the form and process of ecosystems [18] across the terrestrial biosphere, which made the critical transition from mostly wild to mostly anthropogenic, passing the $50 \%$ mark early in the 20th century, between 1700 and 2000 [89].

LULC results in Somone have indicated a very dynamic area related to human pressures, exacerbated by climate change [90]. Thus, coastal lagoons are very dynamic and subject to constant changes, very sensitive and exposed to human pressures, with the development of urban and economic activities such as fishery, aquaculture and tourism [91].

Land use and land cover information, as indicated in this study, provides a rapid and cost-effective means for monitoring and planning coastal area development [91]. Therefore, this study represents a useful tool for the sustainable management of coastal lagoon in Somone and in the whole Senegalese littoral as well, West African littoral.

\section{Conclusion}

Land Use Land Cover Changes were investigated, using satellite images and areal photographers within Somone coastal lagoon for the years 1954, 1978, 2003 and 2016. Results indicated that Somone lagoons have undergone several changes during these periods with mainly the decrease of natural areas such forest areas and rural characteristic areas such croplands, replaced by settlements and tourism infrastructures. These dynamic underscores the urban development of this areas, but also the impacts of climate change with the decrease in rainfall and rising temperature, which have contributed to reduced forest and cropland. Collectively, these results constitute critical information for understanding the dynamic the land use and land cover of these environments and their functioning in the face of climate change and human pressure. Therefore, the results of this study can be applied broadly to devise and/or strengthen policies for sustainable management of tropical coastal lagoons.

\section{Acknowledgements}

This study was undertaken under the framework of WASCAL, a BMBF Germany sponsored program. Authors wish also to thank the Geography and Cartography Direction (DTGC) for their collaboration. This work was carried out at the Cheikh Anta Diop University of Dakar, mainly in the Laboratoire d'Enseignent et de Recherche en
Géomatique/Laboratory of Teaching and Research in Geomatics (LERG).

\section{References}

[1] Green, K., Kempka, D. \& Lackey, L. Using remote sensing to detect and monitor land cover and land-Use change. 1994. Photogrammetric Engineering \& Remote Sensing. 60 (3) 331337.

[2] Tappan, G. G., Hadj, A., Wood, E. C., and Lietzow, R. W. Use of Argon, Corona, and Landsat imagery to assess 30 years of land resource changes in west-central Senegal. 2000, Photogrammetric Engineering and Remote Sensing, 66, 727736.

[3] Rogan, J. \& Chen, D. M. Remote sensing technology for mapping and monitoring land-cover and land-use change. 2004, Progress in Planning. 6, 1301-325.

[4] Shalaby, A. \& Tateishi, R. Remote sensing and GIS for mapping and monitoring land cover and land-use changes in the Northwestern coastal zone of Egypt. 2007, Applied Geography 27, 28-41. doi: 10.1016/j.apgeog.2006.09.004.

[5] Droj, G. GIS and remote sensing in environmental management. 2012, Journal of environmental protection and ecology. 2 (10), 1-7.

[6] Song, D-X., Huang, C., Sexton, J. O., Channan, S., Feng, M. \& Townshend, J. R. Use of Landsat and Corona data for mapping forest cover change from the mid-1960s to 2000s: Case studies from the Eastern United States and Central Brazil. 2014, International Journal of Remote Sensing. XXXXXXX,

http://dx.doi.org/10.1016/j.isprsjprs.2014.09.005.

[7] Nations Unies, (2017). Rapport sur l'Atelier ONU/République islamique d'Iran sur l'exploitation des techniques spatiales pour la surveillance des tempêtes de poussière et des sécheresses dans la région du Moyen-Orient. Téhéran, 5-9 novembre 2016. A/AC.105/1132. p. 13.

[8] Foody, G. M. Status of land cover classification accuracy assessment. 2003. Remote Sensing of Environment 80, 185-201. http://www2.geog.ucl.ac.uk/ mdisney/teaching/teachingNEW /GEOGG141/papers/foody.pdf.

[9] Anderson, J. R. Land use and land cover changes. A framework for monitoring. 1977, Journal of research by Geological Survey. 5, 143-153.

[10] Ingram, K., Knapp, E. and Robinson, J. W. Procedure for change detection using Landsat digital data. 1981, International Journal of Remote Sensing. 2, 277-291.

[11] Singh, A. Change detection in the tropical forest environment of northern India using Landsat. 1986, In: Eden, M., Parry, J. (Eds.), Remote Sensing and Land Management. pp. 237-253.

[12] Singh, A. Digital change detection techniques using remotely sensed data. 1989 International Journal of Remote Sensing 10, 989-1003. http://dx.doi.org/10.1080/01431168908903939.

[13] Lu, D. S., Mausel, P., Batistella, M., Moran, E. Land-cover binary change detection methods for use in the moist tropical region of the Amazon: a comparative study. 2005, International Journal of Remote Sensing 26, 101-114. 
[14] Ban Y, Yousif O. Multitemporal spaceborne SAR data for urban change detection in China. 2012, IEEE J Sel Top Appl Earth Obs Rem Sen 5 (4): 1087-1094.

[15] Du P, Liu S, Gamba P, Tan K, Xia J Fusion of difference images for change detection over urban areas. 2012, IEEE J Sel Top Appl Earth Obs Remote Sens 5: 1076-1086. doi: 10.1109/JSTARS.2012.2200879.

[16] Lu, D. S., Mausel, P., Brondízio, E. S., Moran, E. Change detection techniques. 2004, International Journal of Remote Sensing 25, 2365-2407. http://dx.doi.org/10.1080/0143116031000139863.

[17] Petit, C. C., and Lambin, E. F. Integration of multi-source remote sensing data for land cover change detection. 2001, International Journal of Geographical Information Science, $15,785-803$.

[18] Turner, B. L., Meyer, W. B., \& Skole, D. L. Global landuse/land-cover change: towards an integrated study. 1994, Ambio. Stockholm, 23 (1), 91-95.

[19] Bussi, G., Dadson, S. J., Prudhomme, C., \& Whitehead, P. G. Modelling the future impacts of climate and land-use change on suspended sediment transport in the River Thames (UK). 2016, Journal of hydrology, 542, 357-372.

[20] Almutairi, A. and Warner, T. A. Change Detection Accuracy and Image Properties A Study Using Simulated Data. 2010, Remote Sensing. 2. 1508-1529.

[21] Ban, Y. and Yousif, O. Change Detection Techniques: A Review. In Ban, Y. (ed.) Multitemporal Remote Sensing. 2016, Remote Sensing and Digital Image Processing 20, DOI 10.1007/978-3-319-47037-5 2.

[22] Dwivedi, R. S. Kumar, A. B. \& Tewari, K. N. The utility of multi-sensor data for mapping eroded lands. 1997, International Journal of Remote Sensing. 18 (11), 2303-2318. http://dx.doi.org/10.1080/014311697217620.

[23] Arastoo, B. and Ghazaryan, S. Landcover Changes Detection in Semnan province by Remote Sensing Techniques. 2013, International Journal of Agronomy and Plant Production. Vol., 4 (7), 1637-1644.

[24] Lee, T., Richards, J. A., and Swain, P. Probabilistic and evidential approaches for multisource data analysis. 1987, IEEE Transaction on Geoscience and Remote Sensing, GE-25 (3), 283-293.

[25] Benediktsson, J. A., Swain, P. H., and Ersoy, O. K. Neural network approaches versus statistical methods in classification of multisource remote sensing data. 1990, IEEE Transactions on Geoscience and Remote Sensing, 28 (4), 540-552. http://dx.doi.org/10.1109/TGRS.1990.572944.

[26] Sorberg, A. H. S., Jain, A. K. \& Taxt, T. Multisource classification of remotely sensed data: fusion of Landsat TM and SAR images. 1994, IEEE Transactions on Geoscience and $\begin{array}{lllll}\text { Remote } & \text { Sensing. } & 32 & \text { (4), }\end{array}$ http://dx.doi.org/10.1109/36.298006.

[27] Mouat, D. A., and Lancaster, J. Use of remote sensing and GIS to identify vegetation change in the upper San Pedro river watershed, Arizona. 1996, Geocarto International, 11, 55-67.

[28] Benediktsson, J. A. and Kanellopoulos, I. Classification of multisource and hyperspectral data based on decision fusion. 1999, IEEE Transactions on Geoscience and Remote Sensing,
37 (3), 1367-1377.

[29] Salami, A. T., Ekanade, O., and Oyinloye, R. O. Detection of forest reserve incursion in south-western Nigeria from a combination of multi-date aerial photographs and highresolution satellite imagery. 1999, International Journal of Remote Sensing, 20, 1487-1497.

[30] Bruzzone, L. and Prieto, D. F. Unsupervised change detection in multisource and multisensor remote sensing images. In: Proceedings. 2000, IEEE 2000 international geoscience and remote sensing symposium. Presented at the IGARSS 2000, vol 6, pp 2441-2443. doi: 10.1109/IGARSS.2000.859602.

[31] Tappan, G. G., Hadj, A., Wood, E. C., \& Lietzow, R. W. (2000). Use of Argon, Corona, and Landsat imagery to assess 30 years of land resource changes in west-central Senegal. Photogrammetric engineering and remote sensing, 66 (6), 727 736.

[32] Reid, R. S., Kruska, R. L., Muthui, N., Taye, A., Wotton, S., Wilson, C. J., and Mulatu, W., Land-use and land-cover dynamics in response to change in climatic, biological and socio-political forces: the case of southwestern Ethiopia. 2000, Landscape Ecology, 15, 339-355.

[33] Weng, Q. Land use change analysis in the Zhujiang Delta of China using satellite remote sensing, GIS and stochastic modelling. 2002, Journal of Environmental Management, 64, 273-284.

[34] Amarsaikhan, D. and Douglas, T. Data fusion and multisource image classification. 2004, International Journal of Remote Sensing, 25 (17), 3529-3539.

[35] Stein, A. Use of single- and multi-source image fusion for statistical decision-making. 2005, International Journal of Applied Earth Observation and Geoinformation, 6 (3-4), 229 239.

[36] Ganasri, B. P. \& Aedla, Raju \& Dwarakish, GS. Different Approaches for Land Use Land Cover Change Detection: A Review. Research and Reviews: 2013, Journal of Engineering and Technology. 2. 44-48.

[37] Frihy, O. E. Dewidar, K. M. Nasr, S. M. \& El Raey M. M. Change detection of the northeastern Nile Delta of Egypt: Shoreline changes, Spit evolution, margin changes of Manzala lagoon and its islands. 1998, International Journal of Remote Sensing. $\quad 19 \quad$ (10), 1901-1912. http://dx.doi.org/10.1080/014311698215054.

[38] Cesar, A., Robles, B. and Arturo R-L. Land Use mapping and change detection in the coastal zone of northwest Mexico using remote sensing techniques. 2002, Journal of Coastal Research, 18 (31,514-522. West Palm Beach IFlorida), ISSN 0749-0208.

[39] Calvo, S., G. Ciraolo \& G. L. Loggia. Monitoring Posidonia oceanica meadows in a Mediterranean coastal lagoon (Stagnone, Italy) by means of neural network and ISODATA classification methods. 2003, International Journal of Remote Sensing 24: 2703-2716.

[40] Ahmed, M. H., Leithy, B. M., Thompson, J. R., Ramdani, M., Ayache, F. and Hassan. Application of remote sensing to site characterisation and environmental change analysis of North African coastal lagoons. 2009, Hydrobiologia. 622 (1), 147171. Dio: $10.1007 / \mathrm{s} 10750-008-9682-8$. 
[41] Allen, R. A. Estimating Coastal Lagoon Tidal Flooding and Repletion with Multidate ASTER Thermal Imagery. 2012, Remote Sensing. $\quad 4$, 3110-3126. http://dx.doi.org/10.3390/rs4103110.

[42] CSE, 2015. Rapport sur l' etat de l' environnement du Senegal. P 96.

[43] FAO. Land cover classification system. Classification concepts and user manual. 2005, Software version 2. P. 189. ISBN: 92-5-105327-8.

[44] Clinton, W. J. Release of Imagery Acquired by Space-Based National Intelligence Reconnaissance Systems, Executive Order No. 12951, 22 February 1995, Washington, D. C.

[45] Bouziani, M., Goita, K. \& Dong-Chen, H. Rule-based classification of a Very High-Resolution Image in an urban environment using multispectral segmentation guided by cartographic data. 2010, IEEE Transaction on Geoscience and Remote Sensing. 48 (8), 3198-3211. http://dx.doi.org/10.1109/TGRS.2010.2044508.

[46] Benga, E. Geomorphological study of the mangrove of the Somone estuary. Report "Study of mangroves and estuaries of Senegal Saloum and Somone. 1984, UNESCO-EPEEC, 55-70.

[47] Sakho, I., Mesnage, V., Deloffre, J., Lafite, R., Niang, I., Faye, $\mathrm{G}$. The influence of natural and anthropogenic factors on mangrove dynamics over 60 years: The Somone Estuary, Senegal. 2011, Estuarine, Coastal and Shelf Science. 94, 93101. https://doi.org/10.1016/j.ecss.2011.05.032.

[48] Haack, B., Mahabir, R., \& Kerkering, J. (2015). Remote sensingderived national land cover land use maps: a comparison for Malawi. Geocarto International, 30 (3), 270-292.

[49] Franklin SE, Wulder MA. Remote sensing methods in medium spatial resolution satellite data land cover classification of large areas. 2002, Prog Phys Geogr. 26: 173-205.

[50] Berberoglu S, Akin A. Assessing different remote sensing techniques to detect land use/cover changes in the eastern mediterranean. 2009, Int J Appl Earth Obs Geoinf. 11: 46-53.

[51] M. A. Toure, M. L. Ndiaye, V. B. Traore, G. Faye, B. Cisse, A. Ndiaye, C. T. Wade, P.(2016). Using of Landsat Images for Land Use Changes Detection in the Ecosystem: A Case Study of the Senegal River Delta. International Journal of Environment Agriculture and Biotechnology (ISSN: 24561878). 1 (2), pp. 200-209.

[52] Lillesand, T. M.; Kiefer, R. W. Remote Sensing and Image Interpretation. 1994, 3 rd. (Ed.), John Wiley and Sons, New York, 750.

[53] Sivakumar, R. Image Interpretation of Remote Sensing data. 2010, Geospatial World https://www.geospatialworld.net/article/image-interpretationof-remote-sensing-data/.

[54] Puig, C. J., Hyman, G. and Bolaños, S. Digital Classification vs. Visual Interpretation: a case study in humid tropical forests of the Peruvian Amazon. 2002, http://gisweb.ciat.cgiar.org/sig/download/ghyman/Puig2002Di gitalVsVisual.pdf.

[55] Karsenty, A. Questioning rent for development swaps: new marketbased instruments for biodiversity acquisition and the land-use issue in tropical countries. 2007, International Forestry Review, 9 (1), 503-513.
[56] Yoon G. W., Cho S. I., Jeong S., Park J. H., Object oriented classification using Landsat images. 2010, p. 1-3.

[57] Congalton, R. G., and Green, K. Assessing the Accuracy of Remotely Sensed Data: Principles and Practices. 1999. Lewis Publishers, Boca Raton, Florida, 137 p.

[58] Richards, J. A. Remote Sensing Digital Image Analysis, 5th ed.; 2006, Springer: Heidelberg, Germany.

[59] Duman, K., Eryildirim, A., \& Cetin, A. E.). Target detection and classification in sar images using region covariance and co-difference. In Algorithms for Synthetic Aperture Radar Imagery XVI (Vol. 7337, p. 73370P). 2009, April International Society for Optics and Photonics.

[60] Jensen, K. R. Phylogenetic systematics and classification of the Sacoglossa (Mollusca, Gastropoda, Opisthobranchia).1996, Philosophical Transactions of the Royal Society of London. Series B: Biological Sciences, 351 (1335), 91-122.

[61] Gumma, M. K., Thenkabail, P. S., Teluguntla, P., Rao, M. N., Mohammed, I. A., \& Whitbread, A. M. Mapping rice-fallow cropland areas for short-season grain legumes intensification in South Asia using MODIS $250 \mathrm{~m}$ time-series data. 2016, International Journal of Digital Earth, 9 (10), 981-1003.

[62] Congalton, R. G. A review of assessing the accuracy of classifications of remotely sensed data. Remote Sens. Environ. $1991, \quad 37, \quad 35-46 . \quad \mathrm{http}: / / d x . d o i . o r g / 10.1016 / 0034-$ 4257(91)90048-B.

[63] Girard M. C. \& Girard C. M. 1999. Traitement des données de télédétection. DUNOD Ed. Paris, pages 326 à 334.

[64] Justine M. Caractérisation de la dynamique d'occupation du sol de la ville de Kissangani (R. D. Congo) et sa périphérie entre 2002 et 2010, Master en Bioingénieur en gestion des forêts et des espaces naturels. 2012, Université de Liège, 99 pages.

[65] Chen, G., G. J. Hay, L. M. T. Carvalho, and M. A. Wulder. "Object-Based Change Detection." 2012, International Journal of Remote Sensing 33 (14): 4434-4457. doi: 10.1080/01431161.2011.648285.

[66] Hussain, M., D. Chen, A. Cheng, H. Wei, and D. Stanley. "Change Detection from Remotely Sensed Images: From Pixel-Based to Object-Based Approaches." 2013, ISPRS Journal of Photogrammetry and Remote Sensing80: 91-106. doi: 10.1016/j.isprsjprs.2013.03.006.

[67] Lunetta, R. S., D. M. Johnson, J. G. Lyon, and J. Crotwell. "Impacts of Imagery Temporal Frequency on Land-Cover Change Detection Monitoring." 2004, Remote Sensing of Environment89 (4): 444-454. doi: 10.1016/j.rse.2003.10.022.

[68] Yan, G., Mas, J. F., Maathuis, B. H. P., Xiangmin, Z., \& Van Dijk, P. M. Comparison of pixel-based and object-oriented image classification approaches - a case study in a coal fire area, Wuda, Inner Mongolia, China. 2006, International Journal of Remote Sensing, 27 (18), 4039-4055.

[69] Fichera, C. R., Modica, G., \& Pollino, M. Land Cover classification and change-detection analysis using multitemporal remote sensed imagery and landscape metrics. 2012, European Journal of Remote Sensing, 45 (1), 1-18.

[70] Perez, M. J.; Kobayashi, H.; Matsumura, I. Analysis of land use change in Comayagua County, Honduras, based on remote sensing and field survey data. J. 2005, JASS, 21, 199-208. 
[71] Batar, A. K., Watanabe, T. and Kumar, A. Assessment of Land-Use/Land-Cover Change and Forest Fragmentation in the Garhwal Himalayan Region of India. 2017, Environments 2017, 4, 34; doi: 10.3390/environments4020034.

[72] Congalton, R., and MacLeod, R., 1994, Change detection accuracy assessment on the NOAA Chesapeake Bay Pilot Study. Proceedings of the 1st International Symposium on the Spatial Accuracy of Natural Resource Data Bases, W illiamsburg, V irginia (Bethesda, Maryland: American Society for Photogrammetry and Remote Sensing), pp. 78-87.

[73] Macleod, R. D. and Congalton, R. G. Quantitative Comparison of change-detection Algorithms for monitoring Eelgrass from Remotely Sensed Data. 1998, Photogrammetric Engineering ad Remote Sensing, 64, 207-2016.

[74] Brown, M. S., Goldin, J. G., McNitt-Gray, M. F., Greaser, L. E., Sapra, A., Li, K. T.... \& Aberle, D. R. (2000). Knowledgebased segmentation of thoracic computed tomography images for assessment of split lung function. Medical physics, 27 (3), $592-598$.

[75] Landis J. T. and Koch G. G. The Measurement of observer agreement for categorical data. 1977, Biometrics, 33, 159-174.

[76] Xing, J. and Sieber, R. E. A land use/land cover change geospatial cyberinfrastructure to integrate big data and temporal topology. 2015, International Journal of Geographical Information Science, DOI: $10.1080 / 13658816.2015 .1104534$.

[77] Sakho, I. Evolution et fonctionnement hydro-sedimentaire de la lagune de la Somone, Petite Cote, Senegal., (Sciences de l'environnement. 2011, Universite de Rouen; Universite Cheikh Anta Diop de Dakar), 254.

[78] Cabinet EDE (Environment, Waste, Water), 2016. Etude d'impacts Environnemental et social du dragage de la lagune de Somone. p. 225.

[79] Ruiz-luna, Arturo, John Turner, and Fernando Alonso-p. "Land Cover Changes and impact of Shrimp Aquaculture on the Landscape in the Ceuta Coastal Lagoon System, Sinaloa, Mexico". 2003, 46: 583-600. https://doi.org/10.1016/S09645691(03)00036-X.

[80] Kadeba, A, B M I Nacoulma, A Ouedraogo, Y Bachmann, and A Thiombiano. "Land Cover Change and Plants Diversity in the Sahel: A Case Study from Northern Burkina Faso" 2015, 58 (1): 109-23. https://doi.org/10.15287/afr.2015.350.

[81] Gaglio, Mattias, Vassilis G Aschonitis, Elena Gissi, Giuseppe Castaldelli, and Elisa A Fano.. "Land Use Change Effects on Ecosystem Services of River Deltas and Coastal Wetlands: Case Study in Volano - Mesola - Goro in Po River Delta
(Italy).” 2016, Wetlands Ecology and Management, 20. https://doi.org/10.1007/s11273-016-9503-1.

[82] Campbell, J. B., \& Wynne, R. H. Introduction to remote sensing. 2011, Guilford Press.

[83] Ellis, E. C., Klein Goldewijk, K., Siebert, S., Lightman, D., \& Ramankutty. Anthropogenic transformation of the biomes, 1700 to 2000. 2010, Global ecology and biogeography, 19 (5), 589-606.

[84] Kennish M J and Hans W. P. Coastal Lagoons critical habitat for environmenetal change. 2010, Marine Science series Taylor and Francis group. p. 555.

[85] Stolt, M., Bradley, M., Turenne, J., Payne, M., Scherer, E., Cicchetti, G.... \& Oakley, B. (2011). Mapping shallow coastal ecosystems: a case study of a Rhode Island lagoon. 2011, Journal of Coastal Research, 27 (6A), 1-15.

[86] Mahapatro, D., Panigrahy, R. C. and Panda, S. Coastal Lagoon: Present Status and Future Challenges 2 Classifications of Coastal Lagoons. 2013, International Journal of Marine Science, 3 (23), 178-186. https://doi.org/10.5376/ijms.2013.03.0023.

[87] Duck, R. W and da Silva, J. F. Coastal lagoons and their evolution: A hydromorphological perspective. 2012, Estuarine, Coastal and Shelf Science, 110, 2-14. https://doi.org/10.1016/j.ecss.2012.03.007.

[88] Garrido, J., Pérez-bilbao, A and Benetti, C. J. Biodiversity and Conservation of Coastal Lagoons Ecosystems Biodiversity. 2011, Oscar Grillo and Gianfranco Venora, IntechOpen. P30, DOI: $\quad 10.5772 / 24934$. Available from: https://www.intechopen.com/books/ecosystemsbiodiversity/biodiversity-and-conservation-of-coastal-lagoons.

[89] Viaroli, P., Lasserre, P., \& Campostrini, P. (Eds.). (2007). Lagoons and coastal wetlands in the global change context: impacts and management issues: selected papers of the International Conference" Coast Wet Change", Venice, 26-28 April 2004. Springer.

[90] Barry, N. Y., Traore, V. B., Ndiaye, M. L., Isimemen, O., Celestin, H. and Sambou, B. (2017) Assessment of Climate Trends and Land Cover/Use Dynamics within the Somone River Basin, Senegal. American Journal of Climate Change, 6, 513-538. https://doi.org/10.4236/ajcc.2017.63026 Paulya, D., and Yiiez-arancibiab, A. Fisheries in Coastal Lagoons.1994, 377-399.

[91] Avelar, S., \& Tokarczyk, P. (2014). Analysis of land use and land cover change in a coastal area of Rio de Janeiro using high-resolution remotely sensed data. Journal of Applied Remote Sensing, 8 (1), 083631. 